\title{
CONTEMPORARY ISSUES IN THE GOVERNMENT AND ADMINISTRATION OF LATIN AMERICAN MEGACITIES
}

Peter M. Ward

Department of Sociology Professor at the Lyndon B. Johnson School of Public Affairs, University of Texas, Austin and Director

of the Mexican Center.

RESUMO: Este artigo é o primeiro a analisar e comparar, de modo sistemático, as estruturas dos governos e administraçōes municipais das sete maiores cidades da América Latina: quatro megalópolis (população superior a 10 milhōes de habitantes) e três capitais nacionais. A análise da estrutura dessas administraçōes tem como contraponto as encontradas nos Estados Unidos e Reino Unido. As estruturas governamentais na América Latina apresentam características e tendências importantes: 1. carência de autoridade regional (cruzamento de jurisdiçōes); 2. existência de prefeitos fortes e vereadores fracos; 3 . partidarismo; 4. sobreposição de burocracia ao invés da interligaçāo delas; 5. pressōes a favor da privatização dos serviços municipais, além da continua tensão entre a iniciativa privada e o poder público; 6 . maior autonomia fiscal; 7. contínua marginalização da participação pública no governo das megalópolis. Apesar dessas características , muitas cidades (a despeito de seu tamanho e localizaçāo) estão se esforçando para desenvolver estruturas de governo mais eficazes, responsáveis e democráticas.

ABSTRACT: This paper is the first to systematically analyze and compare the structures of city governance and administration for seven major cities in Latin America, four of which are megacities (population of over 10 million), and three others are large national capitals. U.S. and U. K. models of city administration are reviewed as baseline models against which differences in Latin American may be explored. Structures of Government in Latin America show several important features and trends: 1) the lack of metropolitan (cross jurisdictionall authority; 2) the existence of strong mayors and weak councils"; 3) high levels of partisanship; 4l overlapping rather than interlocking bureaucracies; 5) pressures towards the privatization of city services, but continuing tension over the desirability of public versus private control; 6) greater fiscal responsibility and autonomy; and 7), a continuing marginalization of public participation in megacity governance.In spite of these features, many cities throughout the region (regardless of whether they are megacity size or national capitals), are actively intensifying their efforts to develop more effective, accountable and democratic governance structures.

A preliminary version of this paper was first presented at a meeting on "Latin American Megacities" organized by United Nations University in Mexico City in November 1993.

PALAVRAS-CHAVE: estruturas de governo, administração municipal, megalópolis, América Latina.

KEY WORDS: structures of government, city governance, megacities, Latin America. 
One of the aims of this paper is to go some way to remedy an imbalance that exists in the current literature on megacities. Specifically, the focus 1 propose to take is upon how megacities are administered and governed. All too often structures of city governance are either taken as given or are ignored altogether. Scholars who have analyzed megacities have usually done so through one or more of several optics. First, they have looked at the role of a megacity within the global economy, usually from the point of view of its importance as production, control or financing centres. Prime examples of this work are Friedmann's hypothesis on World Cities, and more recently Sassen' ${ }^{1}$ work on New York, London and Tokyo. A second approach has been to examine the restructuring of these cities, especially the development of control functions to replace their earlier production role $^{2}$. Some authors have also begun to look at the consequences of this restructuring upon poverty and social organization within these cities ${ }^{3}$. A third focus has been to consider the extent to which these cities are becoming more or less similar over time. Particularly relevant here is whether cities in less-developed countries, for example Sao Paulo and Mexico City, are changing physically and culturally in ways similar to their advanced capitalist counterparts. Finally, the perspective adopted by Latin American researchers during the past two decades has tended to delve more thoroughly into systematic aspects of a particular city's development (housing, health care, environmental problems, social movements etc.), generally showing less interest in the city's role in the global economy.

Whichever focus has been used to look at megacities, insufficient consideration has been given to the politicaladministrative structures through which such cities are governed and managed. In the rush to examine their economic base and international roles, scholars have failed to ask fundamental questions about their forms of administration and their governability; almost never have these been examined in a comparative perspective $e^{4}$. How cities are governed tells us much about the nature of power relations and about the opportunities for citizen involvement in the management of the city. Several important dimensions of city governance should be considered. First, what is the basis of legitimacy of the principal government officers? Are they appointed or elected? If elected, is this according to partisan or non-partisan criteria? As I will demonstrate below, some Latin American city governments are constructed on the basis of political party allegiance and others are based on loyalty to individual politicians. The United States has a strong tradition of non-partisanship in local government ${ }^{5}$, particularly since the demise of traditional "machine politics"6. In contrast most voters in the United Kingdom choose their councillors according to the political party each represents, and they know or care little about the person they are electing. Thus, the legitimacy of government varies, as does the form of rationality which will govern an individual's behaviour once in office. Whether a person is appointed or elected, and how they are elected, may determine how they will perform in office - it will also affect the form of their expertise, competence, and even their honesty or softness ${ }^{7}$. The point here is that the structure of a city administration, and the terms under which it is expected to operate, helps to shape the form of citizen involvement in city affairs.

A second issue relates to how activities and power might best be organised when the urban area spreads into the jurisdiction of neighbouring authorities. This is almost uniformly the case for the megacities considered in this article, and is a feature of most large cities throughout the region. Most metropolitan areas in Latin America embrace a number of different administrative units, each of which is vested with a different local authority. These may include areas with special federal jurisdictions (such as the Federal Capital of Buenos Aires and Mexico City's Federal District), states and countries (for example, the Provinces of Buenos Aires and Lima, or the State Government of Sao Paulo), urban authorities (usually municipalities or their equivalent), and so on. The legitimacy and rationale of each will vary. Thus, careful ordering and
1. SASSEN, S. The global city: New York, London, Tokyo. Princeton: Princeton University Press, 1991.

2. O'NEILL, $H$. and MOSS, M. Reinventing New York: competing in the next century's global economy. New York: Urban Research Center, 1991.

3. FATNSTEIN, S., GORDON, I. and HARLOE, $M$. Divided cities: New York and London in comparative perspective. Oxford: Blackwell, 1992.

4. One of the exceptions that prove the rule is ZICCARDI, Alicia. Ciudades y gohiernos locales en America Latina en los noventa. Mexico: Miguel Angel Pomla, 1991.

5. STANYER, J. Understanding local government. London: Fontana, 1976

6. POHLMANN, M. Governing the postindustrial city. London: Longman, 1993.

7. WADE, R. Politics and graft: recruitment, appointment, and promotions to public office in India, in WARD, P. Corruption, Development and Inequality. London: Routledge, 1989, 73109. 
clarification of the various "tiers" of authority are required if city development is to be coordinated in any meaningful ways. Equally important is that the nature of intergovernmental relations between one level of auhority and another needs to be properly understood.

Related to the issue of politicaladministrative organization is a third consideration: what functions should each tier of administration perform (land-use planning, infrastructural development, transportation, social services, service provision, security, cleansing etc)? Specifically, how can these functions be "nested" hierarchically so as to maximise efficiency, equity, access, or whatever the local goals happen to be?

A final dimension of analysis is to identify the opportunities for local self governance. To what extent do the citizens of megacities mobilise politically and how far are they empowered to take genuine

\section{Most metropolitan areas in Latin America embrace a number of different administrative units, each of which is vested with a different local authority.}

8. PATEMAN, C. Particioation and Democratic Theory. Cambridge: Cambridge University Press, 1970.

9. PITKIN, H. Representation. New York: Atherton Press, 1969.

10. SILVERMAN, J. Public sector decentralization: economic policy and sector investment programs. Washington D.C.: World Bank Technical Paper No. $188,1988$.

11. RODRIGUEZ, $V$. and WARD, P. The New PRI: Recasting Its Identity, in AITKIN, R., at. alii. Dismantling the Mexican State? MacMilian, 1996. responsibility for local issues? What is the dominant ideology governing citizenship in each city end how has this ideology been constructed? Drawing upon Pateman ${ }^{8}$, Pitkin ${ }^{9}$ and others' discussion, here two important considerations arise. First, the institutional structures through which citizens participate in city governance representational democracy; and second, the structures and channels through which citizens participate in city governance participational democracy.

In short, these key features of city administration and governance have been neglected in the Latin American literature and have rarely been examined in comparative perspective. Too often government structures have been considered to have evolved independently, responding only to local circumstances and political pressures. Any attempt to change or restructure these governmental arrangements are often fiercely resisted by those who fear an erosion of their powers. Change, if it occurs, tends to be gradual rather, than dramatic. From the local perspective there seems to be little point to comparison. Yet, these structures demand more systematic study, since they are at the heart of what determines whether large cities will be decent places in which to live. For Latin America governments this means coming to terms with new sets of responsibilities that are all too often alien to them. This is one reason why so many key concepts in the public administration field, devolution of power, empowerment and accountability, cannot easily be expressed in either Spanish or Portuguese.

\section{EMERGING IMPERATIVES FOR THE 1990s}

Recent political changes, both in Latin America and beyond, demand that we examine structures of urban governance and administration. First, the democratization process in Latin America has required that governments take a fresh look at the way in which cities are managed. Also, the growing disenchantment that some Latin American populations feel towards their national leaders has led to a resurgence of interest in local government and in a new federalism that shifts the locus of power away from central government, towards greater state and city autonomy.

A second imperative to emerge is the significant shift towards decentralization and devolution. This can occur either within the layers of a city administration or within a single government agency. This process appears emerging strongly in a number of less developed countries, and has found quickening support among international agencies such as the World Bank $^{10}$. In Mexico, for example, austerity measures introduced during the 1980s, along with economic restructuring and political reform, have intensified the need for the local authorities to do more with less. A greater willingness to embrace decentralization and administrative reorganisation has been a direct outcome of this process ${ }^{11}$.

Throughout Latin America, city and 
metropolitan authorities have had to confront cuts in public expenditure, declining subsidies, and often growing pressure to privatise a range of public utilities. As greater fiscal responsibility is being placed at the local level, municipal and state governments are required to raise more of their own revenues. Not surprisingly, people have become more concerned about how their local taxes are spent.

Third, many countries are experiencing a technocratisation of administrative and governmental procedures which is bringing greater transparency to city budgeting and increased efficiency to the delivery of urban services. This takes us back to the concepts of devolution and empowerment, since city administrators today recognise the political benefits of accounting more openly to those they serve. Local groups, often poorly organised and overtly radical in the past, now demonstrate greater realism and pragmatism. They are seeking fewer grandiose changes and a "qualitatively new effect in power relations" ${ }^{12}$. They now want greater opportunities for selfgovernment; so that they can defend their local rights and can participate in the improvement of their neighbourhoods ${ }^{13}$. New social movements are better led and more adept at winning favours from the bureaucracy. Non-government organizations, too, have demonstrated greater pragmatism and efficacy in their relations with local authorities, and in their support for social movements and local communities.

Fourth, as democracy has been extended to formerly authoritarian or oneparty regimes, new governance institutions have been had to be forged based upon representational democracy. This has meant experimentation in recasting traditional state society relations, whether these were patrimonial, corporatist, or dominated by party political machines. It has also invoked a need to consider how civic structures of participation can be created that will change the political (civic) culture of dependency; encourage the involvement of heterogenous socio-economic groups in developing greater consensus in government; and where partisan politics is an important determinant of who gets elected, to achieve a balance in accommodating general citizen needs with a partisan agenda.

These imperatives should encourage us to reflect analytically upon past experiences and to think imaginatively about which structures of city administration and governance within a democratic system appear to work best. They also require us to examine how existing structures might best be modified in order to take account of the new experiences and imperatives that have emerged during the early 1990s.

\section{STRUCTURES OF CITY GOVERNMENT}

Before turning to analyze megacity government structures in Latin America it is interesting to examine the structures of local government in the United States and in the United Kingdom. There are important differences between the two systems, particularly in the role party politics plays in electoral competition for office. In the United States, most city elections are non-partisan - people elect their councillors and mayors without consideration of whether they are Republican or Democrat. In the United Kingdom, the opposite is true; voters choose between candidates almost entirely on the basis of their declared party affiliation. This means that national political parties dominate local government much more in the United Kingdom than in the United States.

\section{City government in the United States}

In the United States, four clear premises underpin local government. First, the people elect their representatives. Second, there is a strong system of checks and balances which protects city government from excessive interference by federal and state administrations. Third, cities have considerable autonomy over many of their own affairs, administering their own taxes, setting their own utility charges, running primary and secondary education, policing themselves and operating their own planning departments. Finally, most local authorities have relatively small populations and may cover only a part or a suburb of a larger urban tract. Most large
12. CASTELLS, M. The urban question. London: Edward Arnold, 1976.

13. the grassroots. London: Edward Arnold, 1983. 


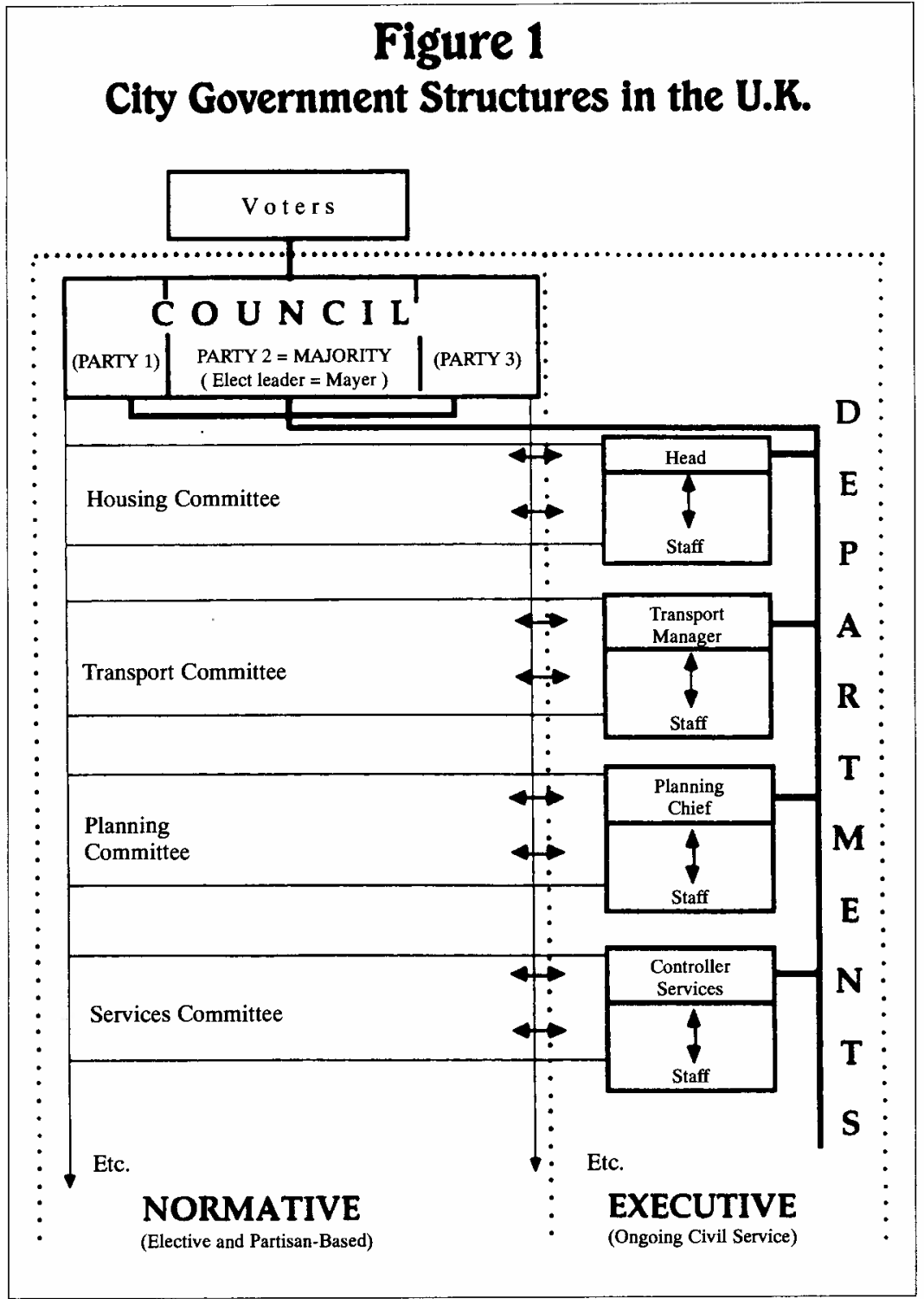

14. This gives residents in those sub-areas (also called cities) considerable local autonomy. Its weakness is that it favours the creation and maintenance of affluent subunits and discriminates against those that are poor. It may lead to a "balkanization" of homone. genous - rich and poor autonomous sub-areas of the larger urban or metropolitan area.

urban areas contain a number of city governments ${ }^{14}$.

Within each city, the administrative structure normally fits one of the three basic models depicted in Figure 1. In each case practices vary for the election of council members: in some cases council members represent individual districts of a city; elsewhere they may be elected "at large", i.e. from across the whole city. Some cities have a mixture of both - with key council positions (the mayor for example) being elected by the whole city electorate.

Strong Mayor-Weak Council: In cities such as Denver and Houston, the mayor has strong powers particularly over the attorney, treasurer, and department heads at city hall). These are important posts because they deal with sensitive areas, such as personal security, civil rights and financial management, which will determine whether the mayor is reelected. The council is highly constrained in the extent to which it can overturn the mayor's decisions.

Weak Mayor-Strong Council: In Atlanta, Los Angeles and San Francisco, the mayor has much less power. The council hires and fires officials by majority vote and the mayor rarely has the right to veto a council decision. Sometimes, key officials are popularly elected, canvassing on the basis of their own mandate, independently of the council or mayor.

The Council City Manager Model: Cities such as Austin or Dallas are run more like business enterprises. The elected council hires a city manager who appoints the city's principal officers and carries full responsibility for running the city's affairs. The manager is accountable to the council and can be dismissed only by majority (or in some places, by a two-thirds majority) vote. The city has a mayor, who often presides over council meetings, but dayto-day decisions are made by the manager. This structure is becoming increasingly common in the United States, particularly in cities with less than 250,000 inhabitants where it predominates. Among the larger cities around half have council managers and of the largest ten cities, four have council managers. selection of key officials (police chief, city
City government in the United Kingdom

Figure 2 shows that British cities are administered by councils. Councillors are elected as representatives of political parties, the vast majority from the Conservative, Labour and LiberalDemocratic parties. The largest party in the council determines policy, if there is no outright majority a coalition between parties is necessary. This parliamentary system is serviced by a hierarchy of civil service officers whose role it is to implement policy.

Professional, non-partisan, officials are appointed by the council and continue in post even when the council changes. These officials service all council committees and 


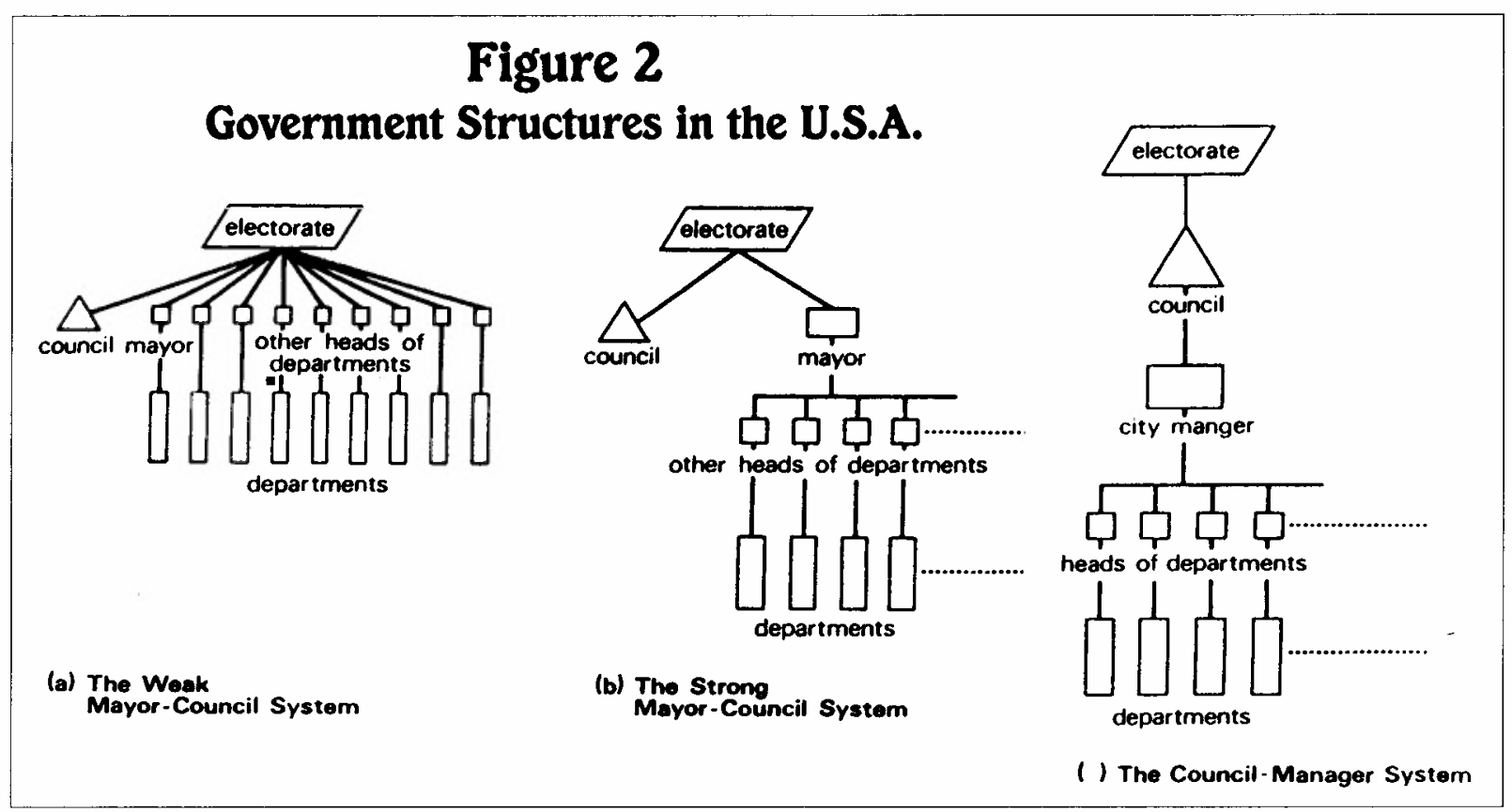

run the city on a daily basis. The key power broker is not the mayor, who presides over the council and whose duties are largely ceremonial, but the council leader. The latter is elected from among the councillors of the majority party. Councils exercise a range of powers at the borough or city level, but are bound by the national laws laid down by Parliament.

Until the 1980s, metropolitan councils existed in London and six other conurbations to manage city-wide issues such as strategic planning and public transport ${ }^{15}$. They were abolished by the Thatcher govemment's wish to break the Labour party's hold over most of these councils, at a time when most metropolitan government policies were almost diametrically opposed to those of the national government.

The principal weakness of local government in Britain is that it is so dependent on central government for its finance.Approximately 70 per cent of local government funding comes from central grants. In addition, the government currently places a series of controls over spending by local authorities. With councils being elected on the basis of political party affiliation, local policy hardly differs from area to area. When local priorities differ from national policy, local government is likely to come under attack.
This description of local government in the United States and Britain offers six basic principles by which large cities in Latin America might be administered. First, urban governments should be democratic. Whatever city administrative and management structure is adopted, those serving in a policy making capacity should be elected. There is no need for the officers in charge of implementing policy to be elected, providing that they are responsible and accountable to the council. Second, city government procedures and decisions should be transparent and all officers and councillors should be publicly accountable. Third, one authority should exist with responsibility for the whole of the city. Such a body should have power over certain metropolitan-wide concerns such as strategic planning, land-using zoning, transport policy, and responsibility for major infrastructures programmes and services. Fourth, all other responsibilities should be decentralised to lower level bodies. Fifth, public participation in government decision-making should be examined and, whenever possible, power should be devolved to local communities and neighbourhoods. Finally, city authorities should have considerable fiscal autonomy. This is important if mandated authorities are to act without interference from higher levels of government.
15. London, Birmingham, Glasgow, Leeds, Manchester, Sheffield and Tyneside. 


\section{No major city in Latin America has a single authority which administers the whole urban area. Most cities are divided between a number of political-administrative units, and although one municipality may be dominant, none has much wish or incentive to collaborate.}

\section{STRUCTURES OF GOVERNMENT IN LATIN AMERICA'S MAJOR CITIES}

The following discussion examines the principal features of government structure and administrative practice in Latin America's major cities and judges them against the above mentioned criteria. The discussion focuses on the four existing megacities, defined as cities with more than ten million inhabitants, as well as drawing upon the experience of other capital cities such as Lima, Caracas, Bogota and Santiago, even though these are not strictly speaking "megacities".

- The lack of a metropolitan authority. No major city in Latin America has a single authority which administers the whole urban area. Most cities are divided between a number of politicaladministrative units, and although one municipality may be dominant, none has much wish or incentive to collaborate. This pattern is particularly marked in the metropolitan area of Sao Paulo, which consists of 39 separate municipalities (one of which - the municipality of Sao Paulo comprises almost $63 \%$ of the total population of Greater Sao Paulo), and in greater Santiago, which is made up of 34 separate communes. Whereas Sao Paulo developed this structure by chance, failing to reform the administrative structure as the metropolitan area grew and absorbed one contiguous municipality after another, Santiago made a conscious decision to adopt it. An administrative reform in 1982 "balkanised" administration in Santiago, giving considerable responsibility to local government over a wide range of municipal matters.
If these two cities represent the extreme in terms of the number of municipal units, several other cities have similar structures. Rio de Janeiro consists of thirteen separate municipalities, Buenos Aires has twenty. local government units and Mexico City falls both under the jurisdiction of the 16 delegated areas of the Federal District and twenty-seven municipalities.

What makes administration particularly complicated is that many of these municipalities themselves are managed by separate higher level administrative units. Mexico City is divided administratively between the Federal District and the State of Mexico. Administration in Buenos Aires is split between the Federal District and the surrounding state of Buenos Aires; the latter having its capital based in La Plata. Administration in Bogota is split between the Federal Capital and the Department of Cundinamarca, and local government in Caracas between the Federal District and the State of Miranda. Indeed, among the largest eight cities of the region only Lima, Rio de Janeiro and Sao Paulo fall withing a single second-tier authority, i.e. a state or a province ${ }^{16}$. The exception is Lima which does have the equivalent of a metropolitan government because the Province of Lima corresponds broadly with the megacity's builtup area and is located within the a single state, the Department of Lima.The division of authority between different second-tier authorities often causes conflict. In Mexico City, for example, the governor of the State of Mexico may be drawn from a different political party, or from a different faction of the same party, to the presidential nominee who runs the Federal District. As a result, there is minimal integration between agencies in the State of Mexico (responsible to the Governor) and those of the Federal District (responsible to the Regente). For example, until recently the metro system operated only in the Federal District; transportation in the State of Mexico was someone else's problem! In Buenos Aires, the national government provides electricity, water and gas in the Federal Capital but the Province of Buenos Aires is responsible for infrastructure in the rest of the city ${ }^{17}$.

This multiplicity of municipal governments combined with different second-tier authorities makes coordinated action across the metropolitan area very 
difficult. Insofar as there is any form of coordination it comes from three sources. The first is that one form of authority in most of these cities is much more powerful than the rest. For example, in Buenos Aires the administration of the Federal Capital (which contains $27 \%$ of the total city population) has far greater influence with central government than the individual municipalities of the Province of Buenos Aires. The Intendente of the Federal Capital holds a national cabinet post and formally runs the municipality on behalf of the central government. Similarly, in Mexico, the Regente of the Federal District holds a cabinet position and has much more political clout than the Governor of the State of Mexico, let alone that of the mayors of the individual municipalities within the State.

A second source of coordination, at least in theory, comes from the consultative bodies which have been established in all four megacities to improve communication between the different administrative units. In practice, however, these bodies achieve little because they threaten existing power structures within each administrative area. As a result, they are little more than "letterhead" bodies with little in the way of effective power.

Finally, specific functions are occasionally managed at a metropolitan level because they are administered by larger scale government agencies although, as will be described below, these are often undergoing privatization. Thus, electricity provision for the whole of Mexico City is run by a federal agency. In Lima's metropolitan area water and electricity are provided by a single public utility (SEDAPAL and ElectroLima respectively). In Bogota, a different mechanism operates: water services in neighbouring municipalities are run under contract by the Bogota water and sewerage company. Sometimes, too, utilities may be provided by a single private company such as the private monopoly CHILECTRA which provides elecricity to Santiago's metropolitan area. In Buenos Aires two private telephone companies provide the service.

- Strong mayors and weak councils. A common feature of local government in most large Latin American cities is the power of the executive relative to the legislature. Much of the problem relates to the weakness of the councils. Unlike some of the mayors, who sometimes hold national cabinet office and often have considerable personal influence, the councils are very weak. Frequently, councils have only nominal powers. In the Federal District of Mexico, although recent reforms have increased the role of the Assembly of Representatives from a consultative to that of a legislative body it remains relatively weak, and in the Federal Capital of Argentina, the Deliberating Council performs a similar role. In both cities, the mayor is appointed by the national president and is the dominant actor. Elsewhere councils have more responsibility but have few real controls over the power of the mayor. The mayor appoints the key department heads, and if the council has committees to monitor their actions, they do little more than act as public 'watchdogs'. Whether it is a municipal president in relation to the cabildo in Mexican municipalities in the State of Mexico, the Prefeito in relation to the Camara de Vereadores in Sao Paulo and Rio de laneiro, the mayor before the Consejos Deliberantes in the municipalities of the Province of Buenos Aires, the mayor holds most of the reins of power.

Only in Santiago de Chile do the municipal councils wield real power. Administration in the city is decentralized and each of the 34 communes directly elects a council for four years. A member of the council is elected as mayor, unless a single councillor has managed to obtain more than 35 per cent of the electoral vote in which case he or she is appointed automatically. The mayor presides over the council but has limited powers to appoint executive officers. Local officials are civil servants, and even department heads continue from one administration to the next. This structure weakens the power of the mayor relative to the council and to the executive.

- The dominant role of partisanship. Unlike the United States, where it is the individual rather than any allegiance to a political group that matters, in Latin 
America party membership is critical. It is certainly much more important than a candidate's individual qualities or his or her competence to fulfil the demands of the job. This is clearly the case where higher political authorities appoint the chief executive as in the Federal District of Mexico. Of course, such a path is not inevitable. In Brazil, recent elections seem to have reduced the power of the political parties. Indeed, while some candidates have won power through their allegiance to a particular party (the case in 1988 of Luiza Erundina's election for the Workers' Party in Sao Paulo being a good example), individual qualities appear to count more. Generally, indeed, party allegiance seems to be fickle and electors are not surprised to find candidates switching parties between elections, or forming splinter groups in loose coalitions. Leonel Brizola is perhaps the classic case of such behaviour. He has twice been elected Prefeito of Rio de Janeiro, is now governor of the State, on each occasion representing a small minority party in coalition with other small parties.

Moreover, as local democracy spreads and electorates become more discerning, political bosses will need to select candidates for office who have some personal credibility and capacity to carry out the job ${ }^{18}$. Also, the growing sense of citizenship and demands for transparency and accountability in Latin American cities is likely to intensify the emerging tension between partymandated policy making and the need to develop sound administrative practices that are less coloured by partisan considerations - as was clearly demonstrated by the Workers' Party attempts to influence the direction of the Luiza Erundina administration ${ }^{19}$.A person's individual qualities, together with a proven capacity to govern effectively and to develop some level of consensus among hetereogenous social, economic and political groups, will be crucial in getting that individual or party reselected to power. While political parties may be expected to increasingly develop specific urban policy platforms and manifestos at election time, and while party affiliation is likely to continue to be an important determinant in elections and appointment to public office throughout Latin America, overt partisanship in the actual practice of city governance is likely to be eschewed, and is probably on the demise.

- Overlappings not interlocking bureaucracies. One of the principal impediments to efetive administration in Latin American cities is the lack of an overall planning authority to coordinate the functions of different sector agencies ${ }^{20}$. This is particularly important insofar as there is sometimes a multiplicity of agencies with competing or parallel responsibilities. This problem is aggravated by the way that the individual agencies ignore one another's needs and programmes and, at worst, actually compete with one another. At times, strong rivalries emerge between departments which seek to develop their programmes in maverick fashion. Where decentralised organizations form an important element of national and municipal goverment, they tend to act independently and make little effort to collaborate ${ }^{21}$. In Bogota, the national housing agency has frequently built homes in areas that the local planning and servicing agencies did not want developed. The housing agency has been keen to develop cheap land even where the public utilities were anxious not to build infrastructure in distant parts of the city. In one notorious instance, a housing estate went without water for three years when the municipal agency refused to supply it.

- Privatisation or municipalisation? One way of cutting through public inefficiency is to privatise state agencies. Privatisation also has other virtues. It removes responsibility for expensive capital investment in infrastructure provision and the costly replacement and maintenance of deteriorated service networks. It also offers governments a means of cutting their budget deficits by bringing in windfall revenues. For these reasons, privatisation is flavour of the decade in Latin America and among the international development banks ${ }^{22}$. Privatization may be achieved in degrees, ranging from contracting out, to private supplements, to full privatisation $^{23}$.

Consequently, several megacities have 
privatised or are in the process of privatising public utilities. In Buenos Aires, the gas company has been sold off, electricity provision and telephones are in private hands, water and sanitation have been privatised through concessions, and even the metro and the suburban railways are candidates for sale. In Lima, the telephone company has been sold off and steps are being taken to reprivatise the water and electricity companies supported by a major loan (US\$300 million) from the World Bank. In Caracas, the electricity, water and telephone companies are now all privately run and, in Santiago, electricity, telephones and cleaning are now in private hands, although parts of the system of water provision and the metro are still run by public companies. By contrast, progress towards the privatisation of public services has been much slower in Mexico City, Rio de laneiro and Sao Paulo. Indeed, the tendency is almost in the other direction. In Rio de Janeiro the private electricity and telephones companies have recently reverted to public ownership. In Mexico City, despite active privatisation at the national level, there has been little divestment of public services. Garbage collection and cleaning services are being opened up to private competition and the telephone system has been privatised, but to date, no moves have been made to sell off the major public utilities or the Metro. One of the city's largest and most important municipalities (Naucalpan) privatized garbage collection in 1993 only to revoke the concession four months later due to public dissatisfaction with the private service. One of the few major successes of the PT administration in Sao Paulo was the public take over of the transport system in $1991^{24}$.Governments in these three cities are subcontracting some activities to the private sector, but they are reluctant to embrace full privatization.

- Fiscal responsibility: doing more with less and more with more. All megacities depend heavily upon transfers of funds from central government and/or from state government. Sometimes, these transfers constitute the lion's share of recurrent expenditure. In addition, urban administrations may seek federal government assistance for special projects, particularly capital investment programmes for urban infrastructure. A common feature of Latin American local finance, therefore, is its heavy dependence upon central government. In addition, urban governments seek major loans from institutions such as the World Bank, although this may dramatically raise their indebtedness and can sometimes undermine the city budget. In Bogota, for example, major infrastructural improvements undertaken during the 1980 s raised the proportion of recurrent expenditure allocated to debt servicing from 14 per cent to 41 per cent between 1980-9025. In 1990, the city was running a deficit almost half of its annual recurrent expenditure. The incoming administration to Sao Paulo in 1988 found that it faced a billion dollar debt and a further $\$ 300$ million in unpaid bills, both of which demanded a total overhaul of city finances.

Cities have different sources of independent local revenues: fees, taxes on production, fines and surcharges, consumption charges, property and title transfer taxes etc. Usually the most important source of local revenue is taxation of local property. Of course, revenues depend upon the quality, coverage and regular updating of the property cadaster and most major cities are busy improving their cadasters. Often, indeed, they are privatising or subcontracting property registration and assessment levies, one way of depoliticizing its operation.

Faced by recurrent deficits and mounting debts, many governments have made a concerted effort to increase their revenues. While locally generated income still represents a small proportion of total income, many local
24. JACOBI, P. Op. cit.

25. LONDONO DE LA CUESTA, 1. Op. cit.

\section{Every government in Latin America also recognises the need to cut expenditure and particularly to stem the flow of resources spent on subsidies.}


authorities have managed to increase their local tax yield. They have raised local property taxes, transfers and sales taxes, taxes or charges on regulatory permissions authorised etc. For the first time in many years there are signs of a political will to introduce realistic levels of taxation and an improving capacity to administer tax collection.

Every government in Latin America also recognises the need to cut expenditure and particularly to stem the flow of resources spent on subsidies. Increasingly governments are reducing subsidies on public transport, infrastructure and services. Private bus companies are receiving fewer subsidies and even public transport companies are being forced to raise fares. In Mexico, the cost of travelling on the metro and the city-run bus system has risen progressively in recent years, although both still remain heavily subsidised. Throughout Latin America charges for water and electricity are increasingly set to cover the full cost of the service. In Santiago, charges for electricity are so high that disconnection for nonpayment is common in low-income settlements. Elsewhere, poorer households are protected through subsidies; the income being recovered either through higher charges on the rich (as in Bogota) or through general taxation.

- Marginalisation of the public from megacity governance. The final feature explored in this paper is the relatively low level of public participation in megacity governance. The traditional absence of public involvement from the planning process in Latin America, and in the case of Mexico City, the effective disenfranchisement of the Federal District population from electing its executive has been described in detail elsewhere ${ }^{26}$. As noted above, the regente of Mexico City is appointed by the national president and in turn selects the local mayors who head the sixteen delegaciones. Only recently have the citizens of the Federal District been given the right to elect any representatives; they now vote for the Asamblea de Representantes, formerly a consultative body which now has some 26. WARD, P. Op. cit. effect become a local congress in 1997. A similar structure exists in the Federal District of Argentina, where the mayor is appointed by the national president and the only vestige of electoral democracy is the elected Consejo Deliberante. Its 60 members are elected by proportional representation but again the council has no legislative powers. This lack of representation is increasingly hard to justify at a time when Latin America is celebrating a high tide of electoral democracy and political openness. At least the Mexican government have announced reforms in the Federal District. From 1997 onwards, the regente will be appointed by the president from among the members of the majority party in the elected Representative Assembly. It is expected that there will be a quickening in attempts to address existing anomalies and inconsistences in terms of the democratic representation of city populations in Latin American megacity governments.

In most other major cities, both the principal executive and the legislature are elected. Even here, however, citizen involvement (participational democracy) is severely constrained by the limited effective powers of local level administration. Several cities have some sort of arrangement for local subcouncils but these are weakly linked to the centre. Residents associations are weak and have little impact on decision-making. There is little clear understanding about how to move from a structure of active social movements and non-government organizations to one of citizen participation in the process of government. To date, there has been a distinct reluctance to empower citizens in Latin America's megacities.

\section{CONCLUSION}

None of the six principles of megacity administration listed earlier are met in any of the Latin American cases analyzed here. The megacity which comes nearest to it is Santiago de Chile which has developed democratic, decentralized and autonomous municipal authorities. It lacks a metropolitan tier of authority, but 
this is less problematic given that so many of the basic utilities are privatised. Its main problem is the lack of resources available to the communes containing large numbers of poor people.

Nevertheless, most megacities are wrestling positively with the issues of more effective public administration and more democratic and open govemment. Today, there is greater transparency and accountability, and more governments are beginning to balance their budgets. Invariably, however, they remain saddled with cumbersome bureaucracies, the different levels and jurisdictions of which are poorly articulated. Most megacities clearly need greater financial and political autonomy. They need greater freedom from interference by higher levels of government so that they can get on with doing the job of running the city. If the party and executive do not comply with their electoral mandate, then they will lose office. There is also a need, it would appear from this review, to create a metropolitanlevel authority with reponsibility for strategic functions such as physical and economic planning, transportation, and primary service provision. Such a body would resemble the former Greater London Council which oversaw such functions for the London boroughs. The Thatcher government abolished the metropolitan councils in Britain because they worked too well: The existence of an elected authority exercising autonomy and implementing policy not of its liking was anathema to conservative central government. However, in my view it is precisely that level of vision and control that is required if Latin American megacities are to develop in a more ordered and democratic way.

Clearly, the legitimacy of megacity governments should be under party political control. The non-partisan citymanager arrangement, so common in the United States, would not work in Latin America. City governments in Latin America will do best if they embrace party politics, rather than be excluded from them, but once elected, representatives must demonstrated even handedness in the disbursement of resources and avoid blatant partisanship ${ }^{27}$. A clear separation must be maintained between party and government if successful governance on behalf of the city is to be achieved.

Finally, and almost as postscript, the question of city size as an intrinsic variable is questioned. This paper has dealt exclusively with seven city cases, only four of which reach the size threshold of megacities. It is necessary to ask whether these megacities confront challenges and issues that are fundamentally different from those faced by smaller metropolitan areas or even rniddle-sized cities? The short answer is no. Although megacities are more complex and invariably transcend several jurisdictions, the challenge is in essence the same: how to administer urban space in a way that is efficient, participatory, accountable and democratic. For the reasons outlined at the beginning of this paper, most cities - large and small - are beginning to confront these challenges. My guess is that because the political stakes are less daunting and the issues are less complex in smaller cities, they will advance more quickly than will the megacities. Certainly many of the most impressive advances I am observing currently come not from megacities but from smaller cities - often governed by political parties different from those at the federal and state levels. Perhaps, megacities will learn best from studying those examples, rather than the other way around.

Acknowledgement: I am grateful to several people for their help in preparing the case study materials upon which the discussion is based. Each was asked to complete a template about 'their' megacity covering: political administrative organisation, bases of governmental legitimacy; government structure; principal activities undertaken by various levels of government; trends towards privatization; city financial arrangements and revenue sharing etc. They were: Luis Ainstein, Henry Dietz, Oscar Figueroa, Alan Gilbert, Milton Santos, Martim Smolka, Hamilton Tolosa and Vilma Faria. Maria Elena Ducci and Manuel Perlo are also thanked for kindly providing additional information about Santiago and Mexico City respectively, as is Terrell Blodgett for his insights on the operation of US city governments. $\square$
27. A recent (November 1995) experiment in Mexico's Federal District to elect citizen counsellors in each of the 16 delegaciones failed badly when only $15 \%$ of those registered to vote went to the polls. This high level of abstentions contrasts markedly with the relatively high voter participation rates for local government elections elsewhere in Mexico. It was due to the government's insistence that, uniquely in the Federal District, candidates be elected along civic (citizen) rather than party political lines. 